\title{
DOES LACK OF POLLINATION EXTEND FLOWER LIFE?
}

\author{
Hannah F. Fung ${ }^{1}$ and James D. Thomson ${ }^{1,2 *}$ \\ ${ }^{1}$ Department of Ecology and Evolutionary Biology, University of Toronto, 25 Harbord Street, Toronto, Ontario, M5S 3G5, Canada \\ ${ }^{2}$ Rocky Mountain Biological Laboratory, Post Office Box 519, Crested Butte, CO 81224-0519, USA
}

\begin{abstract}
Across angiosperm species, the longevity of individual flowers can range from fixed to highly plastic. The orchid family is noteworthy for frequent reports of species in which flower lifespans are greatly prolonged if flowers are not pollinated. Less dramatic cases of pollination-induced senescence of anthesis have been reported for various species in other families, but such reports are scattered. Frequently, such findings are peripheral components of more general pollination studies. Because pollination-dependent plasticity can ameliorate phenological dislocations between plants and pollinators, it is worthwhile to conduct systematic surveys of its magnitude and taxonomic distribution. As a start, we report a set of experiments comparing the active lifespans of pollinated flowers to those of unpollinated controls in a set of nine species from a local subalpine flora. In all species, unpollinated flowers had longer mean times of receptiveness than pollinated ones, although the differences in means were often small. Three species exhibited significantly extended floral longevity in the absence of pollination.
\end{abstract}

Keywords: Plasticity, anthesis, floral longevity, pollination-induced senescence, Rocky Mountain Biological Laboratory

\section{INTRODUCTION}

The longevity of individual flowers varies across plant species; some of the variation is species-specific and genetically determined (Primack 1985; Stratton 1989), and some of it arises from plastic responses to immediate conditions. Here we are concerned with one potential plastic response, the extension of flower life as a response to lack of pollination. Such extension is particularly relevant in the context of recent concerns that climate change can cause phenological mismatches between plants and their pollinators (Kudo et al. 2004; Memmott et al. 2007; McKinney et al. 20I2). As environmental conditions change, plants and pollinators may respond to different cues and emerge at different times, leading to pollination deficits for plants and food shortages for pollinators. The detrimental effects of phenological mismatches can be ameliorated, however, if plants can prolong the lifespans of flowers that have not been pollinated. In Colorado subalpine meadow communities, for example, Forrest \& Thomson (20II, p. $487)$ argued that plant-pollinator dislocations in time are likely to be "quantitative effects... rather than... complete decoupling of formerly interacting organisms." In such situations, the ability of flowers to prolong their lifespans by even a few days might substantially increase the probability of receiving pollinating visits.

Floral longevity, or the length of time that a flower is open and functional (Ashman \& Schoen 1994), has been treated as a resource allocation strategy in which the maintenance of flowers diverts resources from other reproductive or vegetative functions (Schoen \& Ashman 1995; Ashman \& Schoen 1997). Increased floral longevity is likely to increase plant reproductive success through

Received I3 June 20I7, accepted I0 November 2017

*Corresponding author: james.thomson@utoronto.ca prolonged pollen and stigma presentation (Thomson \& Barrett 198I; Lloyd \& Yates I982; Galen et al. I986; Harder \& Thomson 1989), but it also exacts significant carbon and water costs through nectar production, respiration, and transpiration (Ashman \& Schoen 1997). Thus, floral longevity can be viewed as a trade-off between fitness accrual through reproduction and the costs of floral maintenance.

Consequences of this trade-off could be particularly dramatic in many orchid species, where pollination can trigger rapid senescence of flowers that would stay receptive much longer if unpollinated (van Doorn 1997). Pollinationinduced senescence has been reported in diverse genera such as Leporella and Caladenia (Peakall 1989), Encyclia (Ackerman 1989), Cypripedium (Primack \& Hall 1990), Cleistes (Gregg 1991), Calypso (Proctor \& Harder 1995), and Myrmecophila (Parra-Tabla et al. 2009). The effects of reproductive activity on floral longevity are not restricted to female function: in Chloraea alpina, pollinia removal, in addition to deposition, shortened the longevity of unpollinated flowers (Clayton \& Aizen 1996). Similarly, both pollinia removal and deposition induced senescence in Cattleya porcia in an ethylene-dependent process (Strauss \& Arditti 1984).

Orchids are an extreme case. Nevertheless, in other families, floral longevity does respond plastically to the completion of male and/or female function. Effects of pollen deposition on floral lifespan have been reported in numerous families, including Onagraceae (Addicott \& Lynch 1955; Ashman \& Schoen 1997), Caryophyllaceae (Nichols I97I; Motten 1986), Solanaceae (Gilissen 1976, I977), Plantaginaceae (Stead \& Moore 1979, I983), Campanulaceae (Devlin \& Stephenson I984, I985; Richardson \& Stephenson 1989; Evanhoe \& Galloway 2002), Liliaceae (Schemske et al. 1978; Motten I983, I986; Ishii \& Sakai 2000), Portulacaceae (Motten 1986; Aizen 


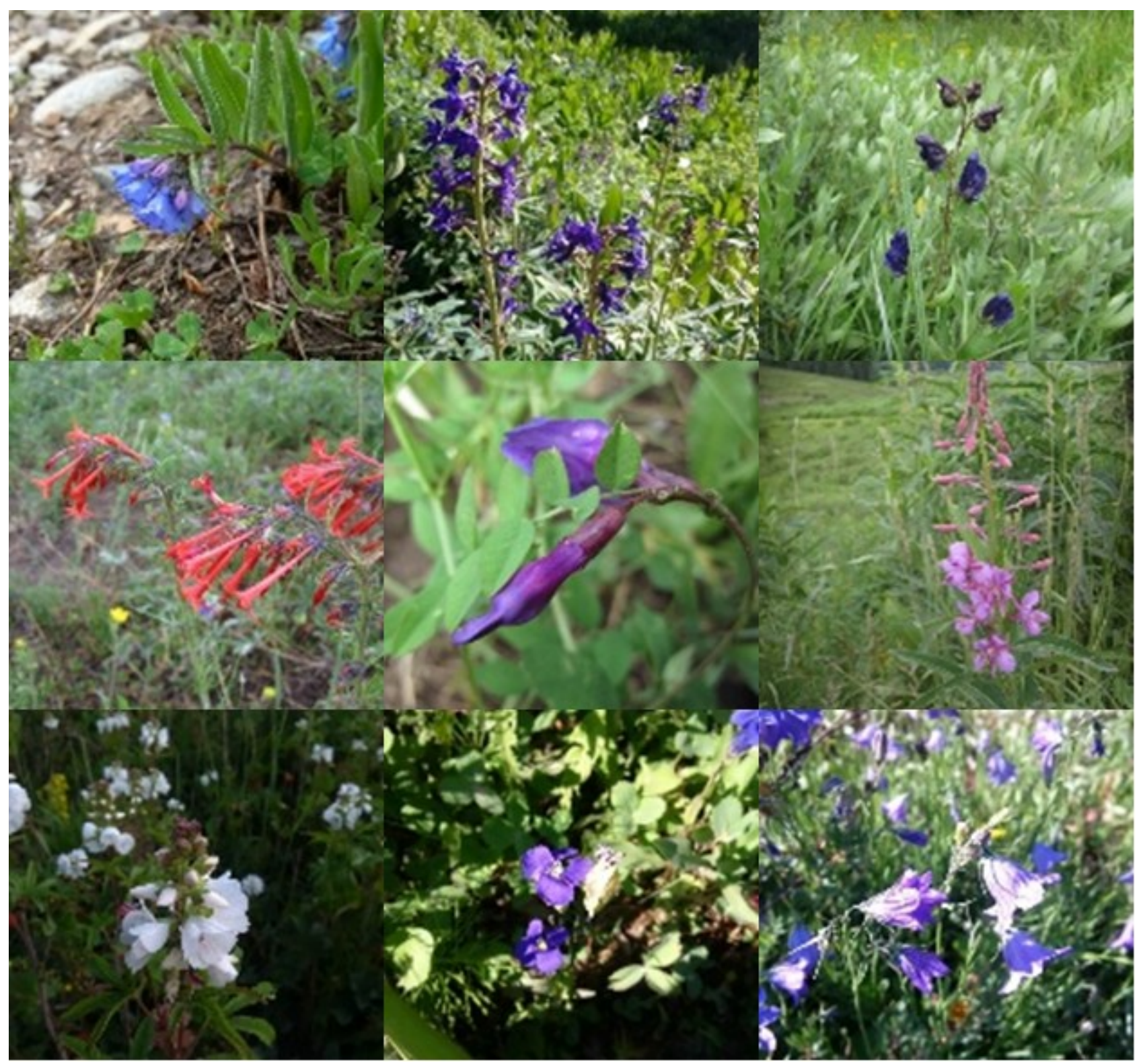

FIGURE I. Photos of nine animal-pollinated species surveyed for pollination-induced senescence in and near the Rocky Mountain Biological Laboratory, Gothic, Colorado. Top row, left to right: Mertensia fusiformis (Boraginaceae), Delphinium barbeyi, Aconitum columbianum (Ranunculaceae); second row, left to right: Ipomopsis aggregata (Polemoniaceae), Vicia americana (Fabaceae), Chamerion angustifolium (Onagraceae); third row, left to right: Sidalcea candida (Malvaceae), Gentianopsis detonsa (Gentianaceae), Campanula rotundifolia (Campanulaceae). All photos by H. F. Fung.

1993), Brassicaceae (Motten 1986; Preston I99I), Gentianaceae (Webb \& Littleton 1987), and Ericaceae (Rathcke 1988a, I988b; Blair \& Wolfe 2007). In Lobelia cardinalis and Campanula rapunculoides, pollen removal and deposition shortened the duration of the staminate and pistillate phases respectively (Devlin \& Stephenson 1984; Richardson \& Stephenson 1989). Interestingly, pollen removal, but not deposition, accelerated senescence in Brassica napus (Bell \& Cresswell 1998).

To broaden the study of pollination-induced senescence and to further explore its implications for phenological mismatch, we surveyed nine plant species (Fig. I) at or near the Rocky Mountain Biological Laboratory (RMBL) in Gothic, Colorado, USA. A great deal of pollination research, including the previously cited study of phenological dislocation by Forrest and Thomson (20II), has been conducted near this field station. In addition, the mating systems and pollinator faunas of most species at Gothic are well-characterized. The species in this study were chosen for convenience: most are abundant, and they produce large, tractable flowers that are characteristically visited by bees or hummingbirds. Using a series of controlled handpollinations, we examined whether plants in this subalpine community can prolong the lifespan of unpollinated flowers.

\section{MATERIALS AND METHODS}

We sampled the nine species at sites within and near the RMBL $\left(38.96^{\circ} \mathrm{N}, 106.99^{\circ} \mathrm{W}, 2900 \mathrm{~m}\right.$ asl) from June to August 2016. To minimize environmental variation, 
individuals of each species were sampled at one site. Prior to flower opening, we covered plants with polyolefin drawstring bags or sand-bag style exclusion bags (Thomson et al. 20I I) to exclude flower visitors.

We marked the pedicels of two flowers, paired for size, floral age, and position on plant, with felt-tipped markers. We chose species-specific markers of floral age that could be scored by gross inspection, such as bud break, stylar exsertion, wilting, colour changes, and abscission (see Appendix I). These easily scored characteristics may not precisely delimit the onset and cessation of flower functions, but we consider them appropriate for detecting differences in floral lifespan in our paired design.

Within pairs, flowers were randomly assigned to experimental or control treatments. Once mature and receptive, experimental flowers were hand-pollinated with Microbrush ${ }^{\circledR}$ applicators (Microbrush International; Grafton, Wisconsin, USA) bearing a mixture of fresh pollen from other plants in the vicinity. We attempted to apply as much pollen as the stigmas could retain. Control flowers were not pollinated, but were manipulated in the same way as experimental flowers with clean applicators. To ensure successful hand pollination, we pollinated each flower twice, on consecutive days. An exception was Campanula rotundifolia, which was hand pollinated three times. Criteria for stigma receptivity are provided in the Supplementary Data.

We checked individuals only once a day. Although more frequent checks could have produced finer-grained data, we compromised so as to be able to score more species and more replicates. We scored flowers for a range of floral age indicators, including extent of anther dehiscence, perianth colour, openness or accessibility to interior (Olesen et al. 2007), degree of wilting, and corolla abscission (details in Supplementary Data). Our response variable, floral lifespan, was the number of days to senescence from first handpollination.

\section{Data analysis}

We used one-tailed exact Wilcoxon signed rank tests to determine whether anthesis was prolonged in unpollinated flowers. Analyses were performed using R v. 3.I.2 (R Foundation for Statistical Computing 2014). Data are expressed as means \pm standard deviation.

\section{RESULTS}

The extension of flower life in unpollinated flowers varied across species (Fig. 2). Based on single Wilcoxon tests, the following species showed evidence of pollination-induced senescence (mean paired differences, control - treatment): Mertensia fusiformis ( $0.67 \pm 0.87$ days, $V=77, P=$ $0.0 \mathrm{II})$, Chamerion angustifolium (0.58 $\pm \mathrm{I} .82$ days, $V=$ I65, $P=0.039)$, and Gentianopsis detonsa $(2.7 \mathrm{I} \pm \mathrm{I} .93$ days, $V=253, P<0.000 \mathrm{I})$. The remaining species did not: Delphinium barbeyi $(0.07 \pm 1.36$ days, $V=150, P=$ 0.58), Ipomopsis aggregata $(2.64 \pm 4.36$ days, $V=161, P$ $=0.14)$, Vicia americana $(0.07 \pm 2.7 \mathrm{I}$ days, $V=90, P=$ $0.3 \mathrm{I})$, Aconitum columbianum (0.56 \pm 2.17 days, $V=\mathrm{I} 47$,
$P=0.058)$, Sidalcea candida (0.26 \pm 0.62 days, $V=52, P$ $=0.19)$, and Campanula rotundifolia $(0.33 \pm 2.09$ days, $V$ $=39, P=0.6 \mathrm{I})$. Despite the lack of significance for the majority of the species, it is worth noting that control flowers had longer estimated mean lifetimes in all nine species, which is itself a highly significant pattern by sign test $(P=0.0039)$.

\section{DISCUSSION}

This study represents one of the few attempts to explore pollination-mediated senescence across species within a local community. Of the nine species surveyed in and near the RMBL, three showed individually significant evidence of pollination-induced senescence (Fig. 2). Overall, unpollinated flowers did tend to last longer, but for the majority of species the differences were too small and inconsistent to overcome the substantial variation within treatments. In further studies, larger sample sizes would be desirable. Our results suggest that species vary in their ability to prolong the lifespan of unpollinated flowers, a finding that is consistent with other broad surveys of floral longevity. In a study of the spring wildflower community in North Carolina, pollen deposition triggered floral senescence in five of eight species (Motten 1986). Likewise, pollinationinduced senescence was observed in four of six shrub species in The Great Swamp, Rhode Island, USA (Rathcke I988b). Evidently, meaningful plasticity in floral lifespan is common but not universal.

Flowers of Gentianopsis detonsa responded to pollination in a similar fashion to two closely related species, Gentiana saxosa and $G$. serotina. In addition to changes in colour and turgor, pollination caused the corollas of these species to close (H. F. Fung, pers. obs.; Webb \& Littleton 1987), which may protect the developing ovary from predators and subsequent pollinations (Webb \& Littleton 1987). Thus, corolla closure may be a common response to pollination among the gentians. Interestingly, we did not find evidence of pollination-induced senescence in Campanula rotundifolia (Fig. 2), in contrast to studies of $C$. rapunculoides (Richardson \& Stephenson 1989) and $C$. americana (Evanhoe \& Galloway 2002).

From a resource allocation perspective, pollinationinduced senescence offers a way in which plants can plastically optimize the trade-off between reproductive success and the costs of maintaining flowers (Primack 1985; Harrison \& Arditti 1976; Ishii \& Sakai 2000). Through pollination-induced senescence, plants can direct their resources toward maintaining unpollinated flowers, and in doing so, reduce the likelihood that plants and their pollinators are phenologically mismatched. The findings presented here and elsewhere indicate that certain plants can prolong the lifespans of unpollinated flowers, but it is unclear that this is prevalent enough to ameliorate phenological asynchrony substantially. After all, pollination had no effect on floral longevity in the majority of plant species surveyed in the present study.

There are several reasons why floral longevity may not evolve to respond plastically to pollination. First, the trade- 

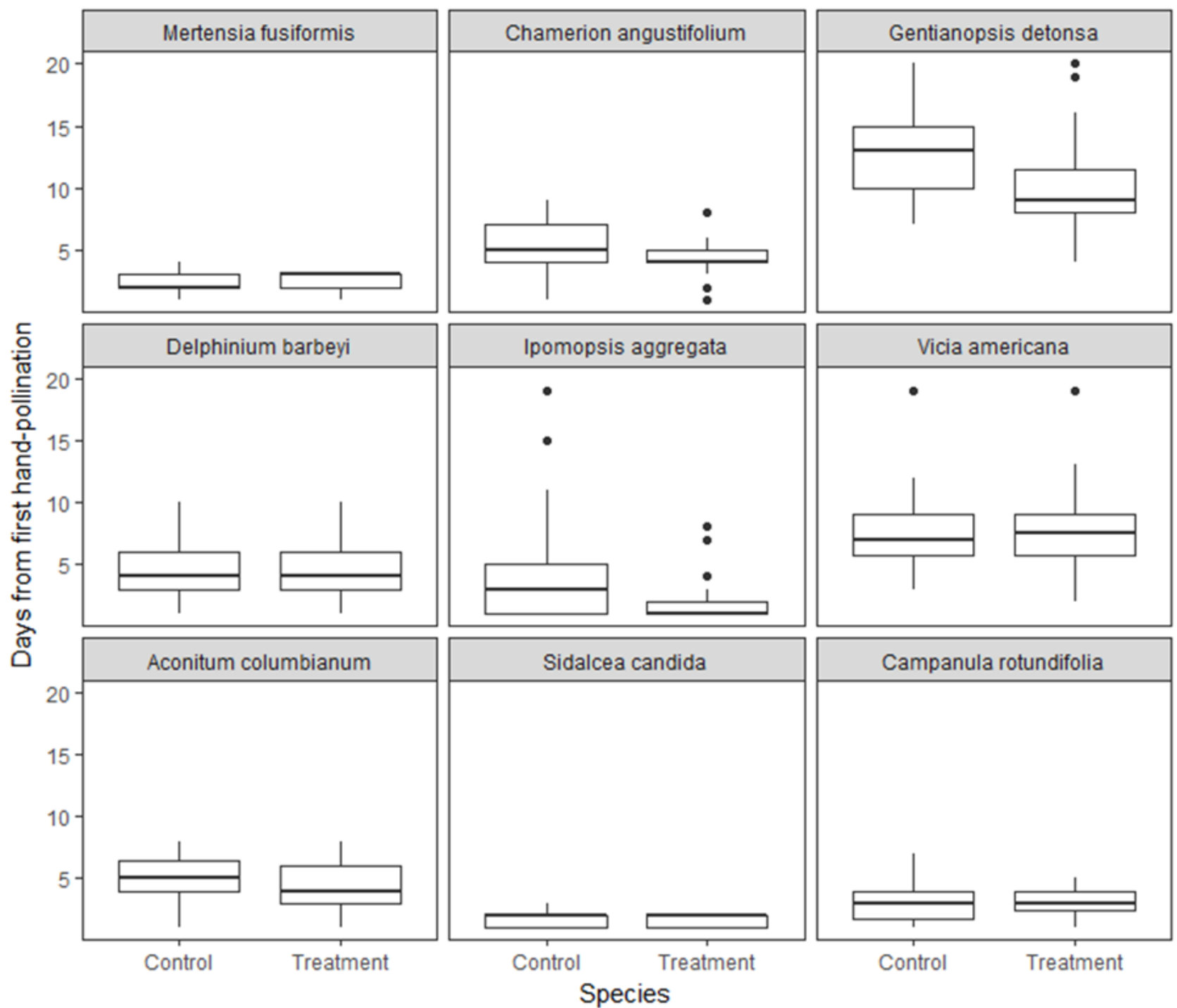

Control

Treatment

FIGURE 2. Floral longevity of nine plant species in or near the Rocky Mountain Biological Laboratory, Gothic, Colorado, USA. Experimental flowers were hand-pollinated once receptive, while control flowers were not pollinated. Sample sizes, in pairs, for the species, in order from left to right, top to bottom: $13,25,19,29,28,28,27,26,18$.

off between reproductive success and maintenance costs may not be as pronounced in plants that continue to grow and photosynthesize after reproduction (Ashman \& Schoen 1997). In the snow buttercup Ranunculus adoneus, for example, flowers accounted for a significant proportion of carbon assimilation (Galen et al. 1993). Similarly, in Ambrosia trifida L., reproductive structures contributed $41 \%$ and $57 \%$ of the carbon required to construct male and female inflorescences respectively (Bazzaz \& Carlson 1979). Moreover, increased photosynthesis in adjacent leaves may compensate for some of the costs of floral maintenance (Gifford \& Evans I98I; Lehtilä \& Syrjänen 1995; Ashman \& Schoen 1997). Such cases are more complicated than the simple concept of allocation from a fixed pool of resources.

Second, plants may continue to maintain pollinated flowers to increase floral display size and to facilitate longdistance attraction of pollinators (Primack 1985; reviewed by Snow et al. 1996; Evanhoe \& Galloway 2002). As display size increases, pollinator visitation tends to increase, increasing pollen export and receipt. Large displays, however, can represent a significant drain on resources (Evanhoe \& Galloway 2002) and can increase the rate of geitonogamy (Barrett \& Harder 1996; Snow et al. I996).

Finally, flowers can contribute to male reproductive success even after they are pollinated (Primack 1985; Ishii \& Sakai 2000). In Erythronium japonicum, for example, floral longevity was nearly constant in flowers pollinated between days one and I2 of anthesis (Ishii \& Sakai 2000). This I2day period was subsequently shown to be necessary for $E$. japonicum flowers to shed the majority of their pollen (Ishii \& Sakai 2000). Based on these results, Ishii \& Sakai (2000) proposed that flowers have a genetically determined minimum longevity that functions to facilitate male reproduction.

This 'minimum longevity' hypothesis yields the following prediction: pollination-induced senescence should be more common in species in which senescence in response 
to pollination does not interfere with pollen dispersal, as in protandrous species (Ashman \& Schoen 1996; Ishii \& Sakai 2000; Evanhoe \& Galloway 2002). There is some evidence that protandrous species are more likely to show pollinationinduced senescence. In a survey of spring wildflowers in North Carolina, Motten (1986) found that weakly protogynous and protandrous species were more likely to senesce in response to pollen deposition than protogynous species. In the present study, however, pollination significantly accelerated senescence in only two of seven protandrous species (Fig. 2).

To address this apparent discrepancy, it is important to recognize that floral longevity may be governed by the pollination status at the plant level, as opposed to the flower level. In other words, plants in which the majority of ovules have been fertilized may present shorter-lived flowers than their unpollinated counterparts. As a result, among-plant comparisons may reveal instances of pollination-induced senescence that were not detected at the within-plant level, as in the cases of Delphinium, Ipomopsis, Vicia, Aconitum, Sidalcea, and Campanula (Fig. 2).

To conclude, we observed significant pollinationinduced senescence in three out of nine study species in and near the RMBL, but the magnitudes of those effects were small-half a day to a few days. Regarding our motivating question of phenological dislocation, plastic extensions of floral lifespan may frequently have trivial effects. Still, species of particular interest should be examined individually.

\section{APPENDICES}

Additional supporting information may be found at the end of this article:

APPENDIX I. Criteria for measuring floral age, stigma receptivity, and senescence.

\section{REFERENCES}

\section{References}

Ackerman JD (1989) Limitations to sexual reproduction in Encyclia Krugii (Orchidaceae). Systematic Botany I4:I0I-I09.

Addicott FT, Lynch RS (1955) Physiology of abscission. Annual Review of Plant Physiology 6:2I I-238.

Aizen MA (1993) Self-pollination shortens flower lifespan in Portulaca umbraticola H.B.K. (Portulacaceae). International Journal of Plant Sciences 154:4I2-4I5.

Ashman T-L, Schoen DJ (I994) How long should flowers live? Nature 37I:788-79I.

Ashman T-L, Schoen DJ (1996) Floral longevity: fitness consequences and resource costs. In: Lloyd DG, Barrett SCH (eds) Floral biology. Chapman and Hall, New York, pp II2-I39.

Ashman T-L, Schoen DJ (I997) The cost of floral longevity in Clarkia tembloriensis. An experimental investigation. Evolutionary Ecology II:289-300.

Barrett SCH, Harder LD (1996) Ecology and evolution of plant mating. Trends in Ecology and Evolution II:73-79.

Bazzaz FA, Carlson RW (1979) Photosynthetic contribution of flowers and seeds to reproductive effort of an annual colonizer. New Phytologist 82:223-232.
Bell SA, Cresswell JE (1998) The phenology of gender in homogamous flowers: temporal change in the residual sex function of flowers of oil-seed rape (Brassicus napus). Functional Ecology I2:298-306.

Blair AC, Wolfe LM (2007) The association between floral longevity and pollen removal, pollen receipt, and fruit production in flame azalea (Rhododendron calendulaceum). Canadian Journal of Botany 85:4I4-4I9.

Clayton S, Aizen MA (1996) Effects of pollinia removal and insertion on flower longevity in Chloraea alpina (Orchidaceae). Evolutionary Ecology 10:653-660.

Devlin B, Stephenson AG (1984) Factors that influence the duration of the staminate and pistillate phases of Lobelia cardinalis flowers. Botanical Gazette 145:323-328.

Devlin B, Stephenson AG (1985) Sex differential floral longevity, nectar secretion, and pollinator foraging in a protandrous species. American Journal of Botany 72:303-310.

Evanhoe L, Galloway LF (2002) Floral longevity in Campanula americana (Campanulaceae): A comparison of morphological and functional gender phases. American Journal of Botany 89:587591.

Forrest JRK, Thomson JD (20II) An examination of synchrony between insect emergence and flowering in Rocky Mountain meadows. Ecological Monographs 8I:469-49I.

Galen C, Dawson TE, Stanton ML (1993) Carpels as leaves: Meeting the carbon cost of reproduction in an alpine buttercup. Oecologia 95:187-193.

Galen C, Shykoff JA, Plowright RC (1986) Consequences of stigma receptivity schedules for sexual selection in flowering plants. The American Naturalist I27:462-476.

Gifford RM, Evans LT (I98I) Photosynthesis, carbon partitioning and yield. Annual Review of Plant Physiology 32:485-509.

Gilissen LJW (1976) The role of the style as a sense organ in relation to the wilting of the flower. Planta I3I:20I-202.

Gilissen LJW (1977) Style controlled wilting of the flower. Planta I33:275-280.

Gregg KB (I99I) Reproductive strategy of Cleistes divaricata (Orchidaceae). American Journal of Botany 78:350-360.

Harder LD, Thomson JD (1989) Evolutionary options for maximizing pollen dispersal of animal pollinated plants. The American Naturalist 133:323-344.

Harrison CR, Arditti J (1976) Post-pollination phenomena in orchid flowers. VII. Phosphate movement among floral segments. American Journal of Botany 63:91 I-918.

Ishii HS, Sakai S (2000) Optimal timing of corolla abscission: experimental study on Erythronium japonicum (Liliaceae). Functional Ecology I4:I22-128.

Kudo G, Nishikawa Y, Kasagi T, Kosuge S (2004) Does seed production of spring ephemerals decrease when spring comes early? Ecological Research 19:255-259.

Lehtilä K, Syrjänen K (1995) Positive effects of pollination on subsequent size, reproduction and survival of Primula veris. Ecology 76:1084-1098.

Lloyd DG, Yates JMA (1982) Intersexual selection and the segregation of pollen and stigmas in hermaphroditic plants, exemplified by Wahlenbergia albomarginata (Campanulaceae). Evolution 36:903-915

McKinney AM, CaraDonna PJ, Inouye DW, Barr B, Bertelsen CD, Waser NM (2012) Asynchronous changes in phenology of migrating broad-tailed hummingbirds and their early-season nectar resources. Ecology 93:1987-1993. 
Memmott J, Craze PG, Waser NM, Price MV (2007) Global warming and the disruption of plant-pollinator interactions. Ecology Letters I0:710-717.

Motten AF (1983) Reproduction of Erythronium umbilicatum (Liliaceae): Pollination success and pollinator effectiveness. Oecologia 59:35I-359.

Motten AF (1986) Pollination ecology of the spring wildflower community of a temperate deciduous forest. Ecological Monographs 56:2I-42.

Nichols R (197I) Induction of flower senescence and gynaecium development in the carnation (Dianthus caryophyllus) by ethylene and 2-chloroethylphosphonic acid. Journal of Horticultural Science and Biotechnology 46:323-332.

Olesen JM, Dupont YL, Ehlers BK, Hansen DM (2007) The openness of a flower and its number of flower-visitor species. Taxon 56(3):729-736.

Parra-Tabla V, Abdala-Roberts L, Rojas JC, Navarro J, SalinasPeba L (2009) Floral longevity and scent respond to pollen manipulation and resource status in the tropical orchid Myrmecophila christinae. Plant Systematics and Evolution 282:III.

Peakall R (1989) The unique pollination of Leporella fimbriata (Orchidaceae): pollination by pseudocopulating male ants (Myrmecia urens, Formicidae). Plant Systematics and Evolution I67:137-I48.

Preston RE (199I) The intrafloral phenology of Streptanthus tortuosus (Brassicaceae). American Journal of Botany 78:10441053.

Primack RB (1985) Longevity of individual flowers. Annual Review of Ecology and Systematics 16:15-37.

Primack RB, Hall P (1990) Costs of reproduction in the pink lady's slipper orchid: A four-year experimental study. The American Naturalist 136:638-656.

Proctor HC, Harder LD (1995) Effect of pollination success on floral longevity in the orchid Calypso bulbosa (Orchidaceae). American Journal of Botany 82:I I3I-II36.

Rathcke B (1988a) Interactions for pollination among coflowering shrubs. Ecology 69:446-457.

Rathcke B (1988b) Flowering phenologies in a shrub community: Competition and constraints. Journal of Ecology 76:975-994.

Richardson TE, Stephenson AG (1989) Pollen removal and pollen deposition affect the duration of the staminate and pistillate phases in Campanula rapunculoides. American Journal of Botany 76:532-538.

Schemske DW, Willson MF, Melampy MN, Miller LJ, Verner L, Schemske KM, Best LB (1978) Flowering ecology of some spring woodland herbs. Ecology 59:35I-366.

Schoen DJ, Ashman T-L (1995) The evolution of floral longevity: Resource allocation to maintenance versus construction of repeated parts in modular organisms. Evolution 49:13I-I39.

Snow AA, Spira TP, Simpson R, Klips RA (1996) The ecology of geitonogamous pollination. In: Lloyd DG, Barrett SCH (eds) Floral biology. Chapman and Hall, New York, pp I9I-2I6.

Stead AD, Moore KG (1979) Studies on flower longevity in Digitalis: Pollination induced corolla abscission in Digitalis flowers. Planta I46:409-4I4.

Stead AD, Moore KG (1983) Studies on flower longevity in Digitalis. The role of ethylene in corolla abscission. Planta I57:15-2I.

Stratton DA (1989) Longevity of individual flowers in a Costa Rican cloud forest: Ecological correlates and phylogenetic constraints. Biotropica 21:308-318.

Strauss MS, Arditti J (1984) Postpollination phenomena in orchid flowers. XII. Effects of pollination, emasculation, and auxin treatment on flowers of Cattleya porcia 'Cannizaro' and the rostellum of Phalaenopsis. Botanical Gazette I45:43-49.

Thomson JD, Barrett SCH (198I) Selection for outcrossing, sexual selection and the evolution of dioecy in plants. The American Naturalist I 18:443-449.

Thomson JD, Forrest JRK, Ogilvie JE (20I I) Pollinator exclusion devices permitting easy access to flowers. Journal of Pollination Ecology 4:24-25.

Thomson JD, Thomson BA (1992) Pollen presentation and viability schedules in animal-pollinated plants: Consequences for reproductive success. In: Wyatt R (ed) Ecology and evolution of plant reproduction: New approaches. Chapman and Hall, New York, pp I-24.

van Doorn WG (1997) Effects of pollination on floral attraction and longevity. Journal of Experimental Botany 48:I6I5-I622.

Webb CJ, Littleton J (1987) Flower longevity and protandry in two species of Gentiana (Gentianaceae). Annals of the Missouri Botanical Garden 74:5I-57. 


\section{APPENDICES}

Appendix I. Criteria for measuring floral age, stigma receptivity, and senescence.

\begin{tabular}{|c|c|c|c|}
\hline Species & Floral age & Stigma receptivity & Senescence \\
\hline $\begin{array}{l}\text { Mertensia fusiformis } \\
\text { Boraginaceae }\end{array}$ & $\begin{array}{l}\text { - Extent of dehiscence } \\
\text { - Openness or accessibility to } \\
\text { interior (Olesen et al. 2007) }\end{array}$ & $\begin{array}{l}\text { Assumed flowers were } \\
\text { receptive when open } \\
\text { Hand-pollinated on days } 2 \& \\
3 \text { of opening }\end{array}$ & Corolla abscission \\
\hline $\begin{array}{l}\text { Delphinium barbeyi } \\
\text { Ranunculaceae }\end{array}$ & $\begin{array}{l}\text { - Extent of dehiscence } \\
\text { - Openness }\end{array}$ & $\begin{array}{l}\text { Day } 3 \text { of anthesis } \\
\text { (Luo et al. 20I4) }\end{array}$ & Corolla abscission \\
\hline $\begin{array}{l}\text { Aconitum columbianum } \\
\text { Ranunculaceae }\end{array}$ & $\begin{array}{l}\text { - Extent of dehiscence } \\
\text { - Openness } \\
\text { - Corolla size }\end{array}$ & $\begin{array}{l}\text { Day } 4 \text { of anthesis } \\
\text { (Luo et al. 20I4) }\end{array}$ & Corolla abscission \\
\hline $\begin{array}{l}\text { Ipomopsis aggregata } \\
\text { Polemoniaceae }\end{array}$ & $\begin{array}{l}\text { - Extent of dehiscence } \\
\text { - Openness } \\
\text { - Style length } \\
\text { - Corolla length }\end{array}$ & $\begin{array}{l}\text { When stigma trifurcates } \\
\text { (Pleasants I983) }\end{array}$ & Corolla abscission \\
\hline $\begin{array}{l}\text { Vicia americana } \\
\text { Fabaceae }\end{array}$ & $\begin{array}{l}\text { - Extent of dehiscence } \\
\text { - Openness } \\
\text { - Corolla colour }\end{array}$ & $\begin{array}{l}\text { Assumed flowers were } \\
\text { receptive when open } \\
\text { Hand-pollinated on days } 2 \& \\
3 \text { of opening }\end{array}$ & Corolla abscission \\
\hline $\begin{array}{l}\text { Chamerion angustifolium } \\
\text { Onagraceae }\end{array}$ & $\begin{array}{l}\text { - Extent of dehiscence } \\
\text { - Openness }\end{array}$ & $\begin{array}{l}\text { When stigma lobes are } \\
\text { reflexed (Galen \& Plowright } \\
\text { I985) }\end{array}$ & Corolla abscission \\
\hline $\begin{array}{l}\text { Sidalcea candida } \\
\text { Malvaceae }\end{array}$ & $\begin{array}{l}\text { - Extent of dehiscence } \\
\text { - Openness } \\
\text { - Style length }\end{array}$ & When stigma is exposed & Wilting and/or closure \\
\hline $\begin{array}{l}\text { Gentianopsis detonsa } \\
\text { Gentianaceae }\end{array}$ & $\begin{array}{l}\text { - Extent of dehiscence } \\
\text { - Openness } \\
\text { - Corolla size }\end{array}$ & When stigma is open & Corolla bleaching \\
\hline $\begin{array}{l}\text { Campanula rotundifolia } \\
\text { Campanulaceae }\end{array}$ & $\begin{array}{l}\text { - Amount of pollen on style } \\
\text { - Openness }\end{array}$ & $\begin{array}{l}\text { When stigma trifurcates } \\
\text { (Nyman 1992) }\end{array}$ & Wilting \\
\hline
\end{tabular}

\section{Cited References:}

Galen C, Plowright RC (1985) The effects of nectar level and flower development on pollen carry-over in inflorescences of fireweed (Epilobium angustifolium) (Onagraceae). Canadian Journal of Botany 63:488-49I.

Luo EY, Ogilvie JE, Thomson JD (2014) Stimulation of flower nectar replenishment by removal: A survey of eleven animal-pollinated plant species. Journal of Pollination Ecology I2(7):52-62.

Nyman Y (1992) Pollination mechanisms in six Campanula species (Campanulaceae). Plant Systematics and Evolution I81:97-I08.

Olesen JM, Dupont YL, Ehlers BK, Hansen DM (2007) The openness of a flower and its number of flower-visitor species. Taxon 56(3):729-736.

Pleasants JM (1983) Nectar production patterns in Ipomopsis aggregata (Polemoniaceae). American Journal of Botany 70(I0):1468-I475. 